\title{
Pengaruh Metode Latihan Dan Motivasi Berprestasi Terhadap Kemampuan Lay Up Shoot Permainan Bola Basket Ekstakulikuler Siswa SMP N 1 Watampone
}

\author{
Muhammad Harliawan ${ }^{1}$, Maria Herlinda Dos Santos ${ }^{2}$, Ardo Okilanda ${ }^{3}$ \\ ${ }^{1}$ Universitas Negeri Makassar, Indonesia, \\ ${ }^{2}$ STKIP Muhammadiyah Bone, Indonesia, \\ ${ }^{3}$ Universitas PGRI Palembang, Indonesia \\ E-mail: muhammad.harliawan@unm.ac.id ${ }^{1}$, mariaherlindasantos@gmail.com², ardo.oku@univpgri- \\ palembang.ac.id ${ }^{3}$,
}

\author{
Menerima: 05 Oktober 2020; Revisi: 03 Maret 2021; Diterima: 27 April 2021 \\ 6) https://doi.org/10.24036/ MensSana.06012021.21
}

\begin{abstract}
The research problem on the lay-up shoot was not well done but the students' dribbling and shooting were good, whether the part training method and the overall training method and achievement motivation had an effect on the basketball lay-up shoot ability. Subjects are 40 students of SMP N 1 Watampone. The method of information analysis is analysis of variance (ANOVA) by level $2 \times 2$ with Tukey's test at the significance level $\alpha=0.05$. The results of the study show (1). The lay-up shoot value of the part training method (A1) was higher than the overall training method (A2) Fo = $5.7396>F t=4.09$ (2). There is an interaction effect of training methods (A) achievement motivation (B) on students' basketball shoot lay-ups (3). The value of the lay-up shoot of basketball in the training method of the large achievement motivation section (A1B1) is greater than the value of the overall training method of the high achievement motivation (A2B1) of the students (4). The value of the lay-up shoot of basketball in the training method of the small achievement motivation section (A1B2) is lower than the overall exercise model of the students' high achievement motivation (A2B2). Lay up shoots should be practiced using the part method because the movement is divided and maximized dribbling and shooting when combined can be easily mastered. Achievement motivation needs to be given by the trainer in every exercise to increase the ability of the lay-up shoot because the level of difficulty of the lay-up shoot movement is quite high, it is necessary to have a larger sample trial, the motivation has an effect on the number of students.
\end{abstract}

Keywords: Methods section training, Methods overall Training, achievement Motivation, Lay up shoot basketball

\section{Abstrak}

Masalah penelitian pada lay up shoot tidak dilakukan dengan baik tapi dribbling dan shooting siswa baik, apakah metode latihan bagian dan metode latihan keseluruhan dan motivasi berprestasi berpengaruh terhadap kemampuan lay up shoot bola basket. Subjek 40 siswa SMP N 1 Watampone. Metode analisis informasi merupakan analisis varians (ANAVA) by level $2 \times 2$ dengan uji Tukey pada tingkatan signifikansi $\alpha=0,05$. Hasil Penelitian menampilkan (1). Nilai lay up shoot metode latihan bagian (A1) lebih tinggi dari metode latihan keseluruhan (A2) $\mathrm{Fo}=5,7396>\mathrm{Ft}=4,09$ (2). Ada pengaruh interaksi metode latihan (A) motivasi berprestasi(B) terhadap lay up shoot bola basket siswa.(3). Nilai lay up shoot bola basket metode latihan bagian motivasi berprestasi besar(A1B1) lebih besar dari nilai metode latihan keseluruhan motivasi berprestasi besar(A2B1) pada siswa.(4). Nilai lay up shoot bola basket metode latihan bagian motivasi berprestasi kecil(A1B2) lebih rendah dari model latihan keseluruhan motivasi berprestasi besar(A2B2) siswa. Lay up shoot harus dilatih dengan metode bagian karena gerakan dibagi dan dimaksimalkan dribbling dan shooting saat digabungkan bisa mudah dikuasai. Motivasi berprestasi perlu terus diberikan pelatih dalam setiap latihan untuk peningkatan kemampuan lay up shoot karena gerakan lay up shoot tingkat kesulitannya cukup tinggi, perlu ujicoba sampel yang lebih besar motivasi berpengaruh pada jumlah siswa. 
Kata Kunci: Metode latihan bagian, Metode latihan keseluruhan, Motivasi berprestasi, lay up shoot bola basket.

\section{PENDAHULUAN}

Cabang olahraga Bola basket menggambarkan permainan olahraga yang banyak digemari oleh warga, salah satunya pada tingkatan pelajar dan pada tingkatan mahasiswa (Mukhtarsyaf et al., 2019). Perihal ini diakibatkan sebab permainan bolabasket menggambarkan berolahraga yang bisa dimainkan dari bermacam kultur kehidupan warga. Permainan bolabasket merupakan salah satu wujud permainan yang tercantum pada olahraga permainan (Swadesi, 2007).

Permainan ini sangat terkenal serta banyak digemari oleh sebagian warga indonesia, paling utama paling digemari oleh warga sekolah (Chauhan et al., 2016) mulai dari tingkatan Sekolah Dasar (SD), Sekolah Lanjutan Tingkatan Pertama (SLTP), Sekolah Menengah Atas (SMA), Sekolah Menengah Kejuruan (SMK), (Oliver, 2007). Perihal ini bisa di amati dari tv luar negara ataupun dalam negara yang menayangkan kegiatan pertandingan Bolabasket ataupun yang bertabiat kilasan( highlight) baik secara langsung ataupun tidak langsung.

Pada permainan bolabasket, seorang pemain dituntut selalu bergerak sambil menerapkan teknik-teknik dasar permainan bolabasket(Ahmadi, 2007), usaha memasukkan bola ke dalam ring lawan sebanyak mungkin tanpa ada kendala dari lawan, dan berusaha menghindari pemain lawan yang ingin memasukkan bola ke dalam ring (Lukyani \& Agustina, 2020).

Hal ini dimaksud pada permainan basket kemampuan lay up shoot merupakan salah satu usaha menambah poin untuk memperoleh kemenangan dalam permainan bolabasket. Hasil observasi di lapangan pada siswa SMP N 1 Watampone melakukan gerakan lay up shoot belum baik hal tersebut terlihat pada koordinasi gerakan yang dilakukan siswa masih belum tersambung atau terhenti seperti adanya jeda.

Siswa juga saat melakukan lay up shoot tidak tepat memasukkan bola ke dalam ring sehingga dengan ini diperlukan metode yang baik serta mutu raga yang mencukupi untuk mengatasi masalah, sebab kenaikan kemampuan dasar permainan bolabasket akan sukses bila pemain melatih fisiknya dengan metode teratur serta berlatih secara terus menerus.

Pelatih yaitu seorang yang ahli dalam bidang tertentu dengan tujuan menunjang olahragawan serta regu dalam menyiapkan penampilan yang prima dalam berolahraga, program latihan merupakan seperangkat aktivitas dalam berlatih yang diatur sedemikian rupa sehingga dapat dilaksanakan oleh siswa pelajar/ atlet, baik menimpa jumlah beban latihan ataupun keseriusan latihannya (Tangkudung \& Pusitorini, 2012).

Prinsip-prinsip latihan merupakan perihal yang harus dikenal oleh seorang pelatih supaya tujuan latihan bisa tercapai cocok dengan tujuannya. Bila prinsip- prinsip latihan ini tidak diaplikasikan bukan saja latihan tidak menggapai target yang di idamkan melainkan bisa menuju kepada latihan yang salah, sehingga program latihan harus betul-betul dibuat dengan terstruktur salah satunya adalah metode latihan untuk meningkatkan keterampilan Lay Up Shoot seorang atlet tidak dapat meningkatkan kemampuan terbaiknya jika tidak di topang dengan latihan yang mumpuni. baik kemapuan dari segi fisik ataupun dari segi kemampuan teknik sehingga sulit untuk berprestasi, prinsip latihan merupakan pedoman serta peraturan secara sistematis yang sangat berhubungan dengan proses latihan(Lubis, 2013).

Prestasi olahraga merupakan salah satu tujuan dalam suatu pembinaan setiap permainan olahraga, tidak semudah yang dibayangkan (Husdarta, 2010). Prestasi tidak serta merta terwujud tanpa adanya beberapa factor penunjang prestasi tersebut, diantaranya; komponen kemampuan fisik, penguasaan teknik dasar kemampuan bola basket (Oliver, 2007).

Seluruh aspek yang sangat komplek tersebut memerlukan sesuatu manajemen yang baik pula buat bisa menghasilkan bahawa berolahraga yang kondusif dalam membangun sesuatu prestasi pada permainan berolahraga bola basket.

Klub olahraga merupakan sebuah wadah dalam berprestasi, dan juga sebagai sumber energi bagi pelatih professional, serta merupakan factor fasilitas yang layak untuk menunjang dalam pembinaan prestasi (Darti, 2018) motivasi sangat memberikan kontribusi besara dalam peningkatan prestasi setiap atlit,

Motivasi bisa dimaksud suatu kekuatan ataupun tenaga pendorong buat melaksanakan suatu perihal ataupun menunjukkan sesuatu perilaku tertentu (Gunarsa, 2008)Motivasi menurut Winardi adalah suatu kekuatan 
potensial yang ada di dalam diri seorang manusia, yang dapat dikembangkannya sendiri atau dikembangkan oleh sejumlah kekuatan luar intrinsik dan ekstrinsik, yang dapat mempengaruhi hasil kerja seseorang secara positif atau secara negatif, tergantung daripada situasi dan kondisi yang dihadapi (Winardi, 2007).

Motivasi menurut Sugihartono diartikan sebagai suatu kondisi yang menyebabkan atau menimbulkan prilaku tertentu dan yang member arah dan ketahanan pada tingkah laku tersebut (Sugihartono et al., 2007). Ada tiga komponen utama dalam motivasi yaitu kebutuhan, dorongan, dan tujuan (dan Mudjiono, 2009). Motivasi mendorong atlet untuk mencapai sesuatu dengan sempurna, meningkatkan kebugaran pada tingkatan tertinggi, dan berlatih secara maksimal.

Motivasi berprestasi pada hakikatnya merupakan keinginan, hasrat, kemauan, dan pendorong untuk dapat unggul yaitu mengungguli prestasi yang pernah dicapainya atau yang dicapai orang lain (Komarudin, 2017). Dengan demikian prestasi bisa dikatakan sesuatu proses latihan raga, taktik, teknik dan mental yang sistematis, intensif, serta berkesinambungan, sesuai peminatan permainan olahraga yang digeluti, dalam perihal ini merupakan permainan bola basket

Game bola basket memiliki 3 kunci dasar keahlian yang wajib ketahui,(1). dribbling,(2). passing,(3). shooting(Lukyani \& Agustina, 2020). Dribbling ialah keahlian bawa bola dengan memantul- mantulnya pada lantai, menuju pada ring lawan, passing ialah keahlian membagikan bola dengan melemparkan kepada sahabat ataupun (mengoper bola basket), sebaliknya shooting ialah keahlian memasukkan bola pada ring lawan(Oliver, 2007). Jika semua keterampilan tersebut dapat dikuasai oleh masing-masing atlet di Sulawesi Selatan, maka sangat memungkinkan untuk mendapatkan juara dalam pertandingan-pertandingan bola basket, baik berskala nasional maupun internasional.

Keberhasilan dalam melaksanakan lay up shoot masih memerlukan pemakaian teknik serta pengambilan langkah yang pas buat mengoptimalkan hasil tembakan tersebut. Gerakan dribbling, passing serta berakhir dengan lay up shoot ke ring lawan (Oliver, 2007). Dalam perihal ini metode ialah salah satu pondasi ataupun dasar untuk seorang buat bisa bermain bolabasket. Banyak metode yang dilatih salah satunya merupakan lay up shoot.

SMP Negeri 1 Watampone memiliki berbagai jenis kegiatan ekstrakulikuler, salah satunya adalah ekstrakulikuler olahraga. Jenis olahraga yang diikut sertakan dalam ekstrakuliler tersebut adalah bolabasket. Berdasarkan hasil pengamatan dalam permainan bola basket ada banyak keuntungan yang kita dapat dalam melakukan lay up shoot dalam permainan bola basket diantaranya ketika melakukan lay up shoot pemain bertahan melakukan pelanggaran dan bola masuk ke ring maka mendapatkan dua angka plus tembakan freethrow. Oleh karena itu, lay up shoot sangat efektif untuk mendapatkan point dalam permainan bola baske.

Seorang pelatih membutuhkan sebuah metode latihan yang bisa meningkatkan kemampuan dalam melakukan lay up shoot, salah satu cara yang dapat digunakan guru dalam meningkatkan kemampuan adalah metode latihan bagian dan keseluruhan (Sukadiyanto \& Muluk, 2011). Tata cara edukasi bagian menggambarkan metode belajar tata cara (aktivitas) yang dilakukan dengan cara bertingkat (berantai ataupun bagian untuk bagian).

Penyampaian modul bimbingan yang dipaparkan dalam bagian-bagian dengan cara terpisah alhasil anak didik bisa memahami tiap faktor ataupun bagian aktivitas terlebih dulu saat sebelum dilanjutkan pada gerakkan berikutnya dengan cara totalitas. Sesudah anak didik memahami serta menguasai elemen-elemen awal dilanjutkan

Berdasarkan penjelasan di atas, peneliti berkeinginan untuk melakukan suatu riset mengenai metode latihan yang digunakan dalam melatih kemampuan Lay up shoot dengan melihat tingkat motivasi yang tinggi dan motivasi berprestasi yang rendah.

\section{METODE}

Metode yang digunakan dalam penelitian ini adalah metode eksperimen lapangan. Sebagaimana dikemukakan (Sugiyono, 2013) bahwa, dalam penelitian ini ada perlakuan (Treatment), dengan demikian 
metode penelitian eksperimen dapat diartikan sebagai metode penelitian yang digunakan untuk mencari pengaruh perlakuantertentu terhadap yang lain dalam kondisi yang terkendalikan (Sugiyono, 2013).

Penelitian ini melibatkan tiga variabel, yakni : (1) Variabel bebas adalah metode latihan bagian dan metode latihan keseluruhan (2) Variabel terikat adalah kemampuan lay up shoot dalam permainan bola basket, dan (3) Variabel atribut yaitu motivasi berprestasi. Desain penelitian atau rancangan penelitian adalah rencana dan struktur penyelidikan yang disusun sedemikan rupa sehingga peneliti akan memperoleh jawaban untuk pertanyaanpertanyaan penelitiannya.

Desain penelitian ini menggunakan rancangan treatment by level $2 \times 2$. Rancangan treatment adalah unit-unit eksperimen ke dalam sel sedemikan rupa secara acak, sehingga unitunit eksperimen dalam setiap sel relatif bersifat homogen. Secara visual desain penelitian ini dapat di gambarkan sebagai berikut :

Tabel 1 Rancangan treatment by level 2 x 2

\begin{tabular}{lcc}
\hline Metode Latihan & $\begin{array}{c}\text { Metode } \\
\text { Latihan } \\
\text { Bagian } \\
\text { (A1 }\end{array}$ & $\begin{array}{c}\text { Metode } \\
\text { Latihan } \\
\text { Keseluruhan } \\
\text { (A2) }\end{array}$ \\
$\begin{array}{l}\text { Motivasi } \\
\text { Berprestasi(B) }\end{array}$ & ) & A2B1 \\
\hline Tinggi (B1) & A1B1 & A2B2 \\
Rendah (B2) & A1B2 & \\
Total & & \\
\hline
\end{tabular}

Populasi yang dilibatkan dalam penelitian ini adalah siswa ekstrakulikuler SMPN 1 Watampone pada Nopember 2019. Sampel yang digunakan dalam penelitian ini seluruh populasi, (Arikunto, 2010). mengemukakan kalau ilustrasi merupakan beberapa ataupun pengganti dari populasi yang dicermati. Instrumen kemampuan Lay up shoot (Widiastuti, 2011) Beberapa gerakan yang digabungkan sehingga menghasilkan suatu gerakan yang kompleks dalam permainan bola basket.

Penelitian ini menguku motivasi berprestasi dikelompokkan menjadi 2 kategori, yaitu motivasi tinggi dan motivasi rendah (Gunarsa, 2008). Motivasi berprestasi diharapkan dapat memberikan interaksi dengan variabel-variabel lainnya terhadap peningkatan kemampuan lay up shoot siswa ekstrakulikuler 69 SMPN 1 Watampone, jumlah soal motivasi berprestasi terdiri dari 36 soal yang masing soal terdiri dari 5 bagian penilaian yaitu sangat setuju, setuju, ragu-ragu, tidak setuju dan sangat tidak setuju.

Untuk menganalisa data yang terkumpul, digunakan teknik analisis varians (ANAVA) dua arah pada taraf signifikan $\alpha=0,05$ Persyaratan yang diperlukan dalam analisis varians adalah uji normalitas dan homogenitas. Uji normalitas menggunakan uji Lillefors. Sedangkan untuk uji homogenitas menggunakan uji Bartlet. Apabila terdapat interaksi akan dilanjutkan dengan uji Tuckey.

\section{Deskripsi Data}

Gambaran hasil riset dianalisis dan disajikan pada bab ini memuat tentang deskripsi data, pengujian hipotesis, percobaan dugaan, ulasan hasil riset dengan uraian bagaikan selanjutnya: Riset penelitian ini ada 3 jenis variabel, variabel terikat, variabel bebas serta variabel moderator dan atribut variabel terikat merupakan keterampilan dasar lay up shoot dalam game bola basket, faktor bebasnya merupakan tata cara bimbingan bagian serta totalitas, sebaliknya faktor ciri merupakan motivasi berprestasi yang terdiri dari jenis motivasi berprestasi tinggi serta motivasi berprestasi rendah.

Proses latihan yang telah terprogram membagi siswa ke dalam dua kelompok yaitu kelompok siswa yang latihan dengan metode latihan bagian dan metode latihan keseluruhan, maka diperoleh data hasil keterampilan teknik dasar dan motivasi berprestasi dalam permainan bola basket yang berupa skor yang digunakan untuk dianalisis rata-rata hasil penilaian dari empat evaluator atau pelatih. Informasi hasil keterampilan lay up shoot dalam game bola basket yang dipergunakan dalam analisa berbentuk informasi dari hasil evaluasi keterampilan lay up shoot dalam game bola basket serta angka motivasi berprestasi dengan memakai instrumen yang telah dicoba validitasnya( face validity) serta reliabilitasnya

Informasi hasil keterampilan lay up shoot serta motivasi berprestasi dalam game bola basket dianalisis dengan mengakulasi informasi dari tiap- tiap golongan sehabis memperoleh perlakuan. Informasi hasil keterampilan metode dasar serta motivasi berprestasi dalam game bola basket dapat dilihat pada tabel dibawah ini. 
Tabel : Rangkuman Data Hasil Penelitian

\begin{tabular}{|c|c|c|}
\hline $\begin{array}{l}\text { Metode } \\
\text { Latihan (A) }\end{array}$ & \multirow{2}{*}{$\begin{array}{c}\text { Metode } \\
\text { Latihan } \\
\text { Bagiaan } \\
\quad\left(\mathrm{A}_{1}\right)\end{array}$} & \multirow{2}{*}{$\begin{array}{c}\text { Metode } \\
\text { Latihan } \\
\text { Keseluruhan } \\
\left(\mathrm{A}_{2}\right)\end{array}$} \\
\hline $\begin{array}{l}\text { Motivasi } \\
\text { Berprestasi } \\
\text { (B) }\end{array}$ & & \\
\hline \multirow{3}{*}{ Tinggi } & $\Sigma X=72$ & $\Sigma X=56$ \\
\hline & $X=7,2$ & $X=5,6$ \\
\hline & $\begin{array}{l}\mathrm{S}=0,7888 \\
\mathrm{n}=10\end{array}$ & $\begin{array}{c}\mathrm{S}=0,843 \\
\mathrm{n}=10\end{array}$ \\
\hline \multirow{4}{*}{ Rendah } & $\Sigma X=55$ & $\Sigma X=60$ \\
\hline & $X=5,5$ & $X=6$ \\
\hline & $\mathrm{S}=0,971$ & $\mathrm{~S}=0,816$ \\
\hline & $\mathrm{n}=10$ & $\mathrm{n}=10$ \\
\hline \multirow{4}{*}{ Total } & $\Sigma X=127$ & $\Sigma X=116$ \\
\hline & $X=6,35$ & $X=5,8$ \\
\hline & $\mathrm{S}=1,225$ & $\mathrm{~S}=0,833$ \\
\hline & $\mathrm{n}=20$ & $\mathrm{n}=20$ \\
\hline
\end{tabular}

\section{HASIL DAN PEMBAHASAN}

1. Nilai kemampuan lay up shoot bolabasket pada perlakuan metode latihan bagian (A1) lebih tinggi dari nilai metode latihan keseluruhan (A2) siswa.

Kemampuan lay up shoot dalam permainan bola basket merupakan salah satu pola gerak dasar yang sangat penting pada permainan bola basket. Tingkat kesulitan yang cukup tinggi pada lay up shoot sehingga dibutuhkan metode latihan yang cocok di dalam melatih dan meningkatkan lay up shoot. Bersumber pada hasil analisa varian (ANAVA) pada derajat bermakna $\alpha=0,05$, didapat $\mathrm{Fo}=5,7396$ serta $\mathrm{Ft}=$ 4, 09 Dengan seperti itu Fo Ft, maka H0 ditolak, maka bisa disimpulkan jika dengan cara keseluruhan, ada perbandingan yang jelas antara tata cara latihan bagian serta penyebaran kepada keterampilan lay up shoot dalam game bola basket. Angka tata cara latihan bagian $(=6,35$; $\mathrm{SD}=1,2258)$ lebih besar dari angka tata cara latihan keseluruhan $(=5,8 ; \mathrm{SD}=0,8335)$.

Kedua tata cara latihan ini memiliki tujuan yang serupa ialah meningkatkan keterampilan lay up shoot dalam permaian bola basket.yang mana motivasi berprestasi sangat mendukung dalam menghasilkan keterampilan lay up shoot dalam permaian bola basket. yang sangat signifikan, dalam masing- masing tata cara latihan itu mempunyai hasil yang berbeda dalam perspektif hasilnya.

Kesimpulan yang diperoleh dari hasil riset yaitu memberikan masukan bahwa metode latihan bagian sangat cocok digunakan dalam meningkatkan keterampilan lay up shoot dalam permaian bola basket. Karena pelaksanaan metode bagian yang memberikan fokus pada gerakan rangkaian yang terpisah memberi otomatisasi gerak yang baik sehingga akhirnya saat digabungkan dalam satu gerakan lay up shoot yang sebelumnya dribbling dan shooting dapat dilaksanakan dengan baik dan meningkat.

2. Terdapat pengaruh interaksi yang sangat signifikan terhadap metode latihan dan motivasi berprestasi terhadap keterampilan lay up shoot dalam permainan bola basket pada siswa ekstrakulikuler SMPN 1 Watampone .

Hasil analisis varians $2 \times 2$, mengenai interaksi antara tata cara latihan serta motivasi berprestasi kepada keterampilan lay up shoot pada permainan bola basket membuktikan interaksi antara tata cara latihan serta motivasi berprestasi kepada keterampilan lay up shoot dalam game bola basket tampak pada harga total Fo interaksi $(\mathrm{FAB})=14,9774$ serta $\mathrm{Ft}=4$. 09 . Terlihat kalau Fhitung Ftabel, alhasil H0 ditolak. serta H1 diperoleh dengan begitu bisa disimpulkan jika ada interaksi antara tata cara latihan serta motivasi berprestasi kepada keterampilan lay up shoot dalam game bola basket.

Dari hasil penjumlahan serta realitas di
lapangan dimana motivasi berprestasi mempunyai kedudukan yang dapat memberikan pengaruh hasil dari kedua tata cara latihan. Semua ini didukung dari hasil percobaan lanjut yang melainkan antara tata cara latihan bagian dengan motivasi berprestasi tinggi begitu pula motivasi berprestasi rendah serta tata cara latihan keseluruhan dengan motivasi tinggi pula motivasi berprestasi rendah. Keberhasilan angka tata cara latihan bagian dengan motivasi berprestasi tinggi lebih besar dengan cara jelas nampak hasilnya pada angka keterampilan anak didik. 
Kita bandingkan dengan tata cara latihan bagian dengan motivasi berprestasi rendah bisa menciptakan angka yang tidak dapat diprediksi sebab dapat lebih besar dari angka tata cara latihan bagian motivasi rendah. Tata cara latihan bagian serta tata cara latihan keseluruhan keduanya bersama membagikan keberhasilan hasil kepada keterampilan lay up shoot dalam game bola basket cuma saja pada kedua tata cara ini bersama berikan akibat dengan kondisi anak didik tiap- tiap.

Dirumuskan jika untuk anak didik yang mempunyai motivasi berprestasi tinggi apabila ingin menambah kemampuan lay up shoot dalam game bola basket dengan cara terstruktur untuk ditingkatkan satu persatu kemampuan sangat direkomendasikan dilatih dengan memakai tata cara latihan bagian kebalikannya untuk anak didik yang mempunyai motivasi berprestasi kecil lebih baik meningkatkan keterampilan lay up shoot dalam game bolabasket sangat direkomendasika menggunakan latihan keseluruhan.

Karena metode latihan bagian memberi kesan secara berulang dan membuat rasa sedikit jenuh untuk pengulangan ketika berlatih tapi sebenarnya latihan bagian menarik ketika menggabungkan dua gerakan menjadi satu pada akhir latihan. Akhirnya dibutuhkan motivasi tinggi untuk metode latihan bagian yang baik.

3. Hasil perhitungan keterampilan lay up shoot pada permainan bola basket pada perlakuan metode latihan bagian motivasi berprestasi tinggi $\left(A_{1} B_{1}\right)$ lebih tinggi dari nilai metode latihan keseluruhan motivasi berprestasi tinggi $\left(A_{2} B_{1}\right)$ pada siswa ekstrakulikuler SMPN 1 Watampone.

Perbandingan angka golongan motivasi berprestasi tinggi dengan tata cara latihan bagian( P3) dibandingkan dengan golongan motivasi berprestasi tinggi dengan tata cara latihan keseluruhan( P4), didapat $\mathrm{Qh}=11,7945^{*}$ serta $\mathrm{Qt}=3$, 89. Dengan begitu Qhlebih besar dari Qt, alhasil H0 ditolak. Bersumber pada hasil kalkulasi, diterima angka pada umumnya olahragawan yang memiliki motivasi tinggi dengan memakai tata cara latihan bagian( $X=6$, $35 ; \mathrm{SD}=0,880$ ) lebih tinggi dari tata cara latihan keseluruhan $(\mathrm{X}=5,8 ; \mathrm{SD}=0,829$ )

Kedua tata cara ini memiliki tujuan yang serupa ialah memberikan peningkatan performa keterampilan lay up shoot dalam game bola basket, namun tiap- tiap bagian mempunyai perbandingan dalam bidang hasilnya. Untuk anak didik yang mempunyai motivasi besar perihal yang begitu sangat bisa meningkatkan kemampuannya kepada perolehan peningkatan keterampilan lay up shoot dalam game bola basket, sebab mereka lebih berkeinginan besar dalam melaksanakan yang lebih jauh serta dengan cara tertata peningkatan kepada satu persatu metode yang dilaksanakan.

Menganilisis dari nilai yang ada bahwa tata cara latihan bagian dalam penerapannya dengan metode repetisi latihan yang serupa dengan tujuan buat menaikkan ataupun memahami satu persatu teknik yang hendak dilatih agar dapat meraih satu keahlian metode dasar yang betulbetul dapat dipahami dalam penerapannya. Tata cara latihan keseluruhan dalam penerapannya, anak didik yang melaksanakan tata cara latihan keseluruhan tidak dipengaruhi oleh satu fokus metode dalam kemampuan namun dengan cara bersama mengolah metode yang diserahkan dalam satu latihan.

Untuk anak didik yang mempunyai motivasi tinggi, latihan itu ialah aktivitas yang sering dilakukan dan tidak memiliki tantangan yang besar bila cuman dilakukan dalam satu latihan yang mempunyai durasi pendek dengan kewajiban gerakan yang menyeluruh, sebab baginya latihan itu tidak mempunyai satu tujuan perolehan dari metode serta ini simpel semacam ini sering dilakukan bahkan dalam setiap latihan alhasil hal tersebut tidak dapat memunculkan kemampuan yang besar pada metode ini, dengan begitu hasil yang diraih pula tidak sesuai yang diharapkan atau jauh dari yang di inginkan sebelumnya. Maka dari itu, berprestasi dengan penggunaan prosedur latihan keseluruhan untuk anak didik yang mempunyai motivasi tinggi kurang memunculkan antusias memahami metode dasar.

Dari hasil nilai $\mu$ A1B1 $>\mu$ A2B1 sehingga Ho ditolak. Bersumber pada ulasan hasil riset, hingga bisa dianjurkan kalau untuk siswa yang mempunyai motivasi berprestasi tinggi, tata cara latihan bagian lebih sesuai diaplikasikan dalam tingkatkan keterampilan lay up shoot dalam game bola basket.

4. Hasil perhitungan keterampilan lay up shoot dalam game bola baset pada perlakuan latihan bagian motivasi berprestasi rendah( A1B2) lebih kecil dari angka tata cara latihan keseluruhan motivasi berprestasi tinggi( A2B2) pada 


\section{anak didik ekstrakulikuler SMPN 1 Watampone.}

Angka kelompok motivasi berprestasi rendah dengan tata cara latihan bagian( P5) lebih kecil dibandingkan kelompok motivasi berprestasi rendah dengan tata cara latihan totalitas( P6) didapat hasil, $\mathrm{Qo}=3,685$ serta $\mathrm{Qt}=$ 3, 89. Maksudnya, informasi itu tidak terdapat sebab buat menerima $\mathrm{H} 0$, maka bisa ditafsirkan kalau ada perbandingan keterampilan lay up shoot dalam game, tata cara latihan bagian serta tata cara latihan keseluruhan dengan motivasi rendah serta angka tata cara blocked practice motivasi berprestasi tinggi lebih kecil dari angka keterampilan lay up shoot dalam game bola basket tata cara latihan keseluruhan motivasi berprestasi rendah pada anak didik ekstrakulikuler SMPN 1 Watampone.

Dari kesimpulan yaitu kedua tata cara latihan ini memiliki tujuan yang serupa ialah tingkatkan keterampilan lay up shoot dalam game bola basket, namun tiap- tiap mempunyai perbandingan dalam bidang penerapannya. Tata cara latihan bagian dalam penerapannya, dengan metode bagian untuk bagian dalam bimbingan aktivitas dengan harapan dapat memberikan kontribusi yang signifikan dalam peningkatan ataupun pemahaman dalam keterampilan lay up shoot yang hendak dilatih, sebaliknya tata cara latihan keseluruhan dalam penerapannya, menekankan menekuni aktivitas dengan metode keseluruhan aktivitas.

Untuk anak didik yang mempunyai motivasi rendah, latihan semacam ini ialah latihan yang disenangi, sebab baginya latihan itu gerakan- gerakannya dilakukan keseluruhan dalam satu bimbingan aktivitas alhasil mempermudah mempelajarinya tanpa terdapatnya batas membuat anak didik terus menjadi suka dengan perihal itu. Dengan tutur lain, dengan aplikasi tata cara latihan keseluruhan untuk anak didik yang mempunyai motivasi rendah lebih memicu tampaknya antusiasme buat menggapai tingkatan otomatisasi aksi.

Sebaliknya dengan aplikasi tata cara latihan bagian anak didik yang mempunyai motivasi rendah, kurang memicu tampaknya antusiasme dan antusias dalam upaya pendapatan aktivitas keterampilan lay up shoot dalam game bola basket. Maksudnya, informasi itu tidak terdapat sebab buat menerima Ho, alhasil bisa ditafsirkan kalau ada perbandingan keterampilan lay up shoot dalam game bola basket tata cara latihan bagian serta tata cara latihan keseluruhan dengan motivasi rendah.

Hasil penelitian terdahulu menghasilkan kesimpulan pada metode blocked practice "Latihan pada pengulangan yang sama dengan tujuan untuk menguasai dan meningkatkan satu persatu teknik dasar untuk dilatih maka akan mendapatkan hasil satu kemampuan teknik dasar yang sangat dikuasai dalam tugas geraknya"(Okilanda et al., 2020). Artinya ketika metode bagian dilaksanakan dengan maksud menguasai bagian keterampilan gerak akan dapat mencapai hasil lay up shoot yang maksimal, penggabungan kedua bagian gerak menjadi kunci keberhasilan lay up shoot.

Bersumber pada ulasan hasil riset, sehingga penting untuk anak didik pada latihan lay up shoot kedua metode juga memperhatikan faktor latihan fisik pada power otot tungkai, seperti diungkapkan dalam penelitian: Nilai power otot tungkai untuk kemampuan lay up shoot adalah 0.888 (Candra, 2018) dalam materi latihan baik metode latihan bagian atau keseluruhan penting karena besarnya kontribusi daya ledak otot tungkai untuk hasil lay up shoot.

\section{KESIMPULAN}

Secara keseluruhan hasil penelitian ini dapat disimpulkan bahwa hasil keterampilan lay up shoot dalam permainan bola basket dengan penerapan metode latihan bagian lebih tinggi dibandingkan penerapan metode latihan keseluruhan. Mengacu pada kesimpulan penelitian tersebut, maka pada dasarnya bahwa untuk meningkatkan kemampuan lay up shoot dalam permainan bola basket pada siswa perlu diberikan atau diterapkan metode latihan yang spesifik yang sesuai karakteristik keterampilan lay up shoot dalam permainan bola basket.

Penerapan metode latihan bagian ini adalah salah satu metode latihan yang cocok untuk peningkatan keterampilan lay up shoot dalam permainan bola basket. Selain penerapan metode latihan yang diberikan, tidak kalah pentingnya adalah memperhatikan faktor internal seseorang yang ada hubungannya dengan komponen yang akan dikembangkan. Faktor internal individu yang ada kaitannya dengan keterampilan lay up shoot dalam permainan bola basket. 
Hal ini sangat membantu pelatih bahkan siswa untuk memilih metode latihan yang sesuai dan yang akan dikembangkan agar dapat menghasilkan keterampilan lay up shoot lebih baik dalam permainan bola basket pada siswa. Selain itu sebagai pengetahuan untuk pelatih dalam mendesain program latihan untuk siswa dalam mengembangkan metode latihan dan keterampilan lay up shoot dalam permainan bola basket pada siswa.

Hasil temuan dari penelitian yang dilakukan sebagaimana dikemukakan pada kesimpulan di atas menunjukkan bahwa terdapat pengaruh interaksi antara metode latihan dengan dan motivasi berprestasi terhadap keterampilan lay up shoot dalam permainan bola basket. Setelah ditemukannya pengaruh interaksi ini, dapat diartikan bahwa kedua metode latihan memberikan pengaruh yang berbeda terhadap keterampilan lay up shoot dalam permainan bola basket, pada kelompok atlet yang memiliki motivasi berprestasi tinggi ternyata metode latihan bagian lebih tinggi nilai nya dibandingkan metode latihan keseluruhan, sedangkan pada kelompok siswa yang memiliki motivasi berprestasi rendah, metode latihan keseluruhan lebih tinggi nilai nya dibandingkan metode latihan bagian.

Penelitian ini mengindikasikan bahwa motivasi berprestasi perlu dipertimbangkan dalam memperoleh keterampilan lay up shoot dalam permainan bola basket pada siswa. Karena pelaksanaan keterampilan lay up shoot dalam permainan bola basket merupakan salah satu gerakkan untuk mencetak angka dalam permainan bola basket. Keterampilan lay up shoot merupakan suatu rangkain gerakan yang kompleks dengan demikian maka untuk dapat melakukan gerakan yang bai lay up shoot seseorang harus didukung dengan komponenkomponen fisik yang terkait langsung dengan gerakan lay up shoot seperti kecepatan, keseimbangan, kekuatan terutama mempunyai ketepatan yang tinggi.

Dikatakan bahwa untuk meningkatkan keterampilan lay up shoot dalam permainan boloa basket pada siswa perlu melibatkan komponen kondisi fisik. Temuan dalam penelitian ini, bahwa dari data yang diperoleh menunjukan secara keseluruhan hasil keterampilan lay up shoot dalam permainan bola basket dengan penerapan metode latihan bagian lebih tinggi nilai nya dibandingkan penerapan metode latihan keseluruhan. Dapat direkomendasikan bahwa penerapan metode latihan bagian cocok diterapkan dalam meningkatkan keterampilan lay up shoot dalam permainan bola basket.

Bagi siswa yang memiliki motivasi berprestasi tinggi, data yang diperoleh menunjukan bahwa metode latihan bagian memberikan hasil yang lebih tinggi nilai nya dibandingkan metode latihan keseluruhan terhadap keterampilan lay up shoot dalam permainan bola basket. Kita dapat merekomendasikan bahwa metode latihan bagian lebih cocok diterapkan bagi siswa yang memiliki motivasi berprestasi tinggi dalam meningkatkan keterampilan lay up shoot dalam permainan bola basket.

Bagi siswa yang memiliki motivasi berprestasi rendah, data menunjukan bahwa metode latihan keseluruhan memberikan hasil nilai yang lebih tinggi dibandingkan metode keseluruhan terhadap keterampilan lay up shoot dalam permainan bola basket. Kita dapat merekomendasikan bahwa metode latihan keseluruhan lebih cocok diterapkan pada siswa yang memiliki motivasi berprestasi rendah dalam meningkatkan keterampilan lay up shoot dalam permainan bola basket.

\section{DAFTAR PUSTAKA}

Ahmadi, N. (2007). Permainan bola basket. Surakarta: Era Intermedia.

Arikunto, S. (2010). Prosedur Penelitian Suatu Pendekatan Praktik. 2010. Jakarta: Rineka Cipta.

Candra, O. (2018). Contribution of Leg Muscle Explosive Power and Flexibility on LayUp Shoot in Basketball. 2nd Yogyakarta International Seminar on Health, Physical Education, and Sport Science (YISHPESS 2018) and 1st Conference on Interdisciplinary Approach in Sports (CoIS 2018).

Chauhan, D., Patel, N. M., \& Joshi, M. (2016). Automatic summarization of basketball sport video. 2016 2nd International Conference on Next Generation Computing Technologies (NGCT), 670673.

Dani Mudjiono, D. (2009). Teaching and learning. Jakarta: Rineka Cipta. 
Darti, Y. (2018). Pengaruh Kegiatan Ekstrakurikuler Terhadap Prestasi Olahraga Bola Basket Siswa Sekolah Menengah Pertama (SMP) Negeri 4 Palembang. Halaman Olahraga Nusantara (Jurnal Ilmu Keolahragaan), l(2), 190-202.

Gunarsa, S. D. (2008). Psikologi olahraga prestasi. Jakarta: Gunung Mulia.

Husdarta, H. J. S. (2010). Psikologi olahraga. Bandung: Alfabeta.

Komarudin, K. (2017). Psikologi olahraga. Remaja Rosdakarya.

Lubis, J. (2013). Panduan Praktis Penyusunan Program Latihan, Jakarta: PT. Raja Grafindo Persada.

Lukyani, L., \& Agustina, R. S. (2020). Buku Jago Bola Basket. Ilmu Cemerlang Group.

Mukhtarsyaf, F., Arifianto, I., \& Haris, F. (2019). Pengaruh Daya Ledak Otot Tungkai Terhadap Kemampuan Jump Shoot Atlet Klub Bolabasket. Jurnal MensSana, 4(2), 179-185.

Okilanda, A., Dlis, F., Humaid, H., \& Putra, D. D. (2020). Perbedaan Pengaruh Metode Latihan Dan Motivasi Berlatih Terhadap Teknik Dasar Sepakbola Sekolah Sepakbola Beji Timur U-13. Jurnal Educatio FKIP UNMA, 6(1), 80-89.

Oliver, J. (2007). Dasar-dasar bola basket. Bandung: Pakar Raya.

Sugihartono, K. N. F., Harahap, F., Setiawati, F. A., \& Nurhayati, S. R. (2007). Psikologi pendidikan. Yogyakarta: UNY.

Sugiyono, P. D. (2013). Metode penelitian manajemen. Bandung: Alfabeta, $C V$.
Sukadiyanto \& Muluk, D. (2011). Pengantar teori dan metodologi melatih fisik. Bandung: Lubuk Agung.

Swadesi, I. (2007). Buku Ajar Permainan Bola Basket. Singaraja: Universitas Pendidikan Ganesha.

Tangkudung, J., \& Pusitorini, W. (2012). Coaching Sports Achievement Achievement edition II. Jakarta: Smart Jaya.

Widiastuti, W., \& Pd, M. (2011). Tes dan pengukuran olahraga. Jakarta: $P T$. Bumi Timur Jaya.

Winardi, J. (2007). Motivasi dan Pemotivasian. Jakarta: Raja Grafindo Persada. 